\title{
Leaf micromorphology and anatomy of Myrceugenia rufa (Myrtaceae). An endemic coastal shrub of north-central Chile
}

\section{Micromorfología y anatomía foliar de Myrceugenia rufa (Myrtaceae). Un arbusto costero endémico de la zona centro-norte de Chile}

\author{
Hernán A. Retamales ${ }^{1,2^{*}}$, Angel Cabello ${ }^{3}$, María Teresa Serra $^{4}$ \& Tanya Scharaschin ${ }^{1}$ \\ ${ }^{1}$ School of Earth, Environmental and Biological Sciences, Science and Engineering Faculty. Queensland University \\ of Technology. Brisbane, QLD 4001, Australia. \\ ${ }^{2}$ Plant Biology Laboratory, Faculty of Forest Sciences and Nature Conservation, University of Chile, P.O. Box 9206, \\ Santiago, Chile. \\ ${ }^{3}$ Chagual Botanic Garden, Santiago, Chile. \\ ${ }^{4}$ Forestry Herbarium (EIF), Faculty of Forest Sciences and Nature Conservation, University of Chile, P.O. Box 9206, \\ Santiago, Chile. \\ *hernanalfonso.retamales@student.qut.edu.au
}

\begin{abstract}
Species of fleshy-fruited Myrtaceae are generally associated with humid environments and their vegetative anatomy is mainly mesophytic. Myrceugenia rufa is an endemic and rare species from arid zones of the coast of central Chile and there are no anatomical studies regarding its leaf anatomy and environmental adaptations. Here we describe the leaf micromorphology and anatomy of the species using standard protocols for light and scanning electron microscopy. The leaf anatomy of $M$. rufa matches that of other Myrtaceae, such as presence of druses, schizogenous secretory ducts and internal phloem. Leaves of $M$. rufa exhibit a double epidermis, thick cuticle, abundant unicellular hairs, large substomatal chambers covered by trichomes and a dense palisade parenchyma. Leaf characters of $M$. rufa confirm an anatomical adaptation to xerophytic environments.
\end{abstract}

KEYwoRds: Hairs, leaf anatomy, Myrceugenia rufa, Myrtaceae, SEM, xerophytic characters.

\section{RESUMEN}

Las especies con frutos carnosos de Myrtaceae están generalmente asociadas a ambientes húmedos y su anatomía vegetativa es principalmente mesofítica. Myrceugenia rufa es una especie rara y endémica de lugares secos de la costa de Chile central y no hay estudios anatómicos de sus hojas en términos de adaptaciones ambientales. En este artículo describimos la micromorfología y anatomía foliar de la especie usando protocolos estándar para microscopia óptica y electrónica de barrido. La anatomía foliar de $M$. rufa es similar a otras especies de Myrtaceae, en lo que respecta a presencia de drusas, canales secretores esquizógenos y floema interno. Las hojas de M. rufa tienen una epidermis doble, cutícula gruesa, pelos unicelulares abundantes, cavidades subestomáticas amplias y cubiertas por tricomas, y un denso parénquima en empalizada. Los caracteres foliares de la especie confirman una afinidad morfoanatómica a ambientes xerofíticos.

Palabras clave: Anatomía, caracteres xerofíticos, Myrceugenia rufa, Myrtaceae, SEM, tricomas.

\section{INTRODUCTION}

Myrtaceae Juss. is a pantropical family of trees and shrubs with approximately 5500 species, divided into two subfamilies, 17 tribes and 142 genera (Wilson et al. 2005, Govaerts et al. 2008). This family is particularly diverse in the southern hemisphere (Ladiges et al. 2003), with a high diversity in Central America (McVaugh 1968), South America (Landrum 1988) and Australia (Lucas et al. 2007, Thornhill \& Crisp 2012). The members of this family are woody, with entire, simple, evergreen and mostly opposite leaves, with internal phloem and oil glands (Ciccarelli et al. 2008, Cronquist 1981,
Metcalfe \& Chalk 1979). Myrtaceae have polystemonous, mostly bisexual, actinomorphic flowers (Wilson 2011) with partially inferior to fully inferior ovaries (Conti et al. 1996) and usually with a nectariferous hypanthium (Johnson \& Briggs 1984). The fruits are generally classified as either fleshy (berry) or dry (capsular or nut-like), but several other fruit types, such as drupes, and various intermediates, also occur in this family (Wilson 2011). The monophyletic tribe Myrteae (sensu Wilson et al. 2005, Biffin et al. 2010) comprises most of the fleshyfruited Myrtaceae, including the ca. 2500 South American species. In ecological terms, Myrteae species generally occur in humid rainforests or flooded environments, usually wet 
gullies or streams (Kausel 1944, 1957).

The genus Myrceugenia Berg includes 40 species, 14 of which occur in Chile and the remaining in southeastern Brazil (Landrum 1981a, Murillo-A et al. 2012). The Chilean species of Myrceugenia are distributed from the semi-arid centrenorthern region to the moist temperate forests in the southern tip of South America, as well as the Juan Fernandez Islands (Landrum 1981a, 1988). These species are an important component in the upper and middle strata of the temperate forests (Hildebrand-Vogel 2002).

Myrceugenia rufa (Colla) Skottsb. ex Kausel (Myrtaceae: Myrteae) is a shrub 1-2 m high, with reddish-brown hairs on leaves, peduncles, sepals and fruits. The leaves are small, thick, coriaceous, densely pubescent beneath and puberulent above. Peduncles are uniflorous, densely pubescent, solitary or 2-3 in a row in the axils of leaves. Flowers are bisexual, with suborbicular and pubescent calyx lobes and petals, and numerous stamens. The fruits are fleshy, yellowish to orange and pubescent (Landrum 1981a, 1988). The seeds are poorly known; they are frequently eaten by insects (Kausel 1944, Landrum 1981a, 1988).

This species is an exception in the fleshy-fruited Myrtaceae regarding its habitat preference. The species only occurs in the coast of central-north of Chile, in fragmented and open bushlands along ca. $200 \mathrm{~km}$ in the coastline and only few hundreds of meters inland (Landrum 1981a). In this dry habitat, the primary sources of moisture is oceanic breeze from the Pacific Ocean, and some occasional winter rain fall (Landrum 1981a, Serra et al. 1986). Due to this habitat, pubescence and growth habit, the species is considered adapted to xeric environments (Landrum 1981a). Myrceugenia rufa is considered "Rare" by the Red Book on Chilean Terrestrial Flora (Benoit 1989) and "near threatened by the current legislation (MMA 2013), due to its scarcity and fragmented habitat (Kausel 1957). The main threats to the populations stem from urban development and fires (Hechenleitner 2005).

Although several anatomical studies have been performed in Myrtaceae, information regarding Myrceugenia is scarce and mainly limited to wood anatomy (Janssonius et al. 1908, Landrum 1981a, Metcalfe \& Chalk 1979, Ragonese 1978, Record \& Hess 1943, Schmid \& Baas 1984). Leaf anatomy has only been studied in three Brazilian species by Cardoso et al. (2009). The xerophytic condition of M. rufa has never been investigated anatomically. A leaf anatomical and micromorphological study of the species could enhance the understanding of the possible adaptations to drier environments in the family Myrtaceae.

This investigation has three aims: (1) Undertake a complete anatomical and micromorphological description of leaves of $M$. rufa for the first time, (2) determine if these descriptions match or differ from that of other fleshyfruited South American Myrtaceae and (3) assess whether anatomical characters contradict or confirm the xerophytic strategy associated with this species.

\section{MATERIAL AND METHODS}

\section{SPECIMEN SAMPLING}

Sampling was conducted between November 2008 and February of 2014 aiming at representing the entire distribution range of the species. Fully developed leaves from forty-two specimens were collected from the following localities: Quebrada de Cordoba (El Tabo, V Region of Valparaíso; $33^{\circ} 20^{\prime} \mathrm{S}$ ), Los Molles (V Region of Valparaíso; 3240’S), Cerro de la Cruz (Zapallar, V Region of Valparaíso; 32³3'S), Rodelillo (Viña del Mar, V Region of Valparaíso; 3300'S) and Cerro Talinay, IV Region of Coquimbo; 30 50 'S). Samples from cultivated specimens were obtained from the National Botanical Garden (Viña del Mar). Vouchers were collected for representative specimens from certain localities. The material was identified according to Kausel (1944) and Landrum (1981a, 1988).

Specimens (Reta101, Reta102, Reta103 and Reta104) are currently deposited at the Queensland Herbarium (BRI), Brisbane, Australia. Duplicates (Reta101-2, Reta102-2, Reta103-2, Reta104-2) will be deposited at SGO (Museo Nacional de Historia Natural, Chile) and EIF (Facultad de Ciencias Forestales, Universidad de Chile) before publication.

\section{LEAF ANATOMY}

Preparation of histological samples for light microscopy (LM) followed Johansen (1940), Feder and O'Brien (1968), Ruzin (1999) and protocols previously used for Myrtaceae (Belsham \& Orlovich 2003, Donato \& Morretes 2009, Schmid \& Baas 1984, Soh \& Parnell 2011). The samples were fixed in FAA for $48 \mathrm{~h}$, dehydrated through ethanol series, followed by xylene-ethanol combinations $(1: 3,1: 2,1: 1,1: 0) 2 \mathrm{~h}$ each, infiltrated and embedded in paraffin wax. Sections of $5 \mu \mathrm{m}$ thick were cut with an E. Leitz Wetzlar rotary microtome. Sections were stained with safranine O (1\%), fast green, ferric chloride and tannic acid for various periods of time (Johansen 1940). The slides were sealed with Eukitt (acrylic resin-xylene) mounting medium.

\section{LEAF MICROMORPHOLOGY}

Fragments of leaves were fixed in FAA for 24-48h, dehydrated using a graded ethanol series and then critical point dried (Anderson 1951) in an Autosamdri-815 automatic critical point drier. Samples were then mounted on stubs with selfadhesive double-sided carbon discs and sputter-coated with gold palladium during $175 \mathrm{sec}$ using a Leica EM SCD005 Gold Coater. Examination and photography were conducted using a FEI Quanta 200 SEM/ESEM operated at 10kV.

\section{OBSERVATION AND MEASUREMENTS}

Anatomical slides were examined with a Carl Zeiss Axiostar 10-031 microscope equipped with a Canon Power Shot A640 digital camera. Cells were measured and counted on digital micrographs with the UTHSCSA ImageTool 3.0 software (Wilcox et al. 2009). Cells and structures dimensions were 
calculated with 35 random repetitions in different samples of the 42 specimens, in order to obtain representative mean values. Measurements were calculated in micrometers $(\mu \mathrm{m})$ and millimetres $(\mathrm{mm})$ depending upon structure or cell type. Botanical terminology was based on Esau (1953) and Raven et al. (2005). Myrtaceae-specific anatomical descriptions and terminology were based on Schmid (1980), Schmid \& Baas (1984), Cardoso et al. (2009) and Da Silva et al. (2012).

\section{RESULTS}

Micromorphology OF LEAVES

Leaves of $M$. rufa are hypostomatic. Stomata are 8-21 $\mu \mathrm{m}$ long. Leaf stomatal density was determined as $632 \pm 15$ stomata per $\mathrm{mm}^{2}$. The adaxial surface is rich in cuticular waxes, which are highly sinuous and give to the leaf a rough and rugged appearance. The adaxial epidermal cells are irregularly rounded and the anticlinal cell walls are strongly sinuous. On this surface, some scattered hairs are observed growing through wax (Fig. 1 A). Hairs are $125 \pm 15.2 \mu \mathrm{m}$ long. Hairs are unicellular, non-glandular, solitary, dibrachiate, appressed, conical, slightly wavy and persistent (Fig. 1 B). The midrib is strongly impressed on the adaxial surface and slightly prominent on the abaxial side. Secondary veins are not visible.

The abaxial surface is pubescent, with a high density of dibrachiate, apressed and unicellular hairs (Fig. 1 C). The density of hairs covers the stomata almost completely. There are compacted groups of hairs apparently covering substomatal chambers on this surface (Fig. 1 D). The edges of the leaves are slightly revolute.

ANATOMY OF LEAVES

Myrceugenia rufa has dorsiventral leaves covered by a double epidermis of $26 \pm 2.4 \mu \mathrm{m}$ on the adaxial side (Fig. $2 \mathrm{~A}$ ). A prominent cuticle of $6.6 \pm 1.2 \mu \mathrm{m}$ thick covers the adaxial surface of the leaf. On the abaxial side the cuticle is $3.6 \pm 0.8$ $\mu \mathrm{m}$ thick. Epidermal cells are compressed, plano-convex and mainly isodiametric. Stomata are anomocytic (sensu Gifford \& Foster 1989), and large sub-stomatal chambers on the abaxial side are observed in some samples (Fig. 2 A), most times covered by hairs. Some stomata are partially hidden in crypts or depressions on the leaf surface. In transverse section, apressed unicellular hairs are visible on the abaxial surface (Fig. 2 A).

The mesophyll is formed by a compressed 2-4 layered palisade parenchyma and a spongy parenchyma with intercellular spaces. The palisade parenchyma layer is dense and composed of rectangular, attenuated and vertical cells. These cells possess thin primary cell walls and numerous chloroplasts. The spongy parenchyma is composed of irregular shaped cells (rounded to polygonal) (Fig. 2 B). Intercellular spaces correspond to 50$60 \%$ of the transverse area of the mesophyll. Secretory ducts are schizogenous and its average diameter is $95 \pm 15 \mu \mathrm{m}$. These cavities are composed of large spaces surrounded by a sheath of peripheral epithelial cells, which are almost degenerated. Secretory ducts are abundant in all unlignified tissues and have variable dimensions (Fig. 2 C). Idioblasts with calcium oxalate crystals (druses) with a diameter of $25.1 \pm 3.8 \mu \mathrm{m}$, occur throughout the palisade and spongy parenchyma (Fig. 2 D). An extension of the bundle sheath, composed of rounded-polygonal cells, is visible under the midrib. Internal phloem, as a continuous layer or isolated strands occurs on the adaxial side of vascular bundles (Fig. 2 E). Xylem vessels of the midrib show helicoidal thickenings of lignified secondary cell walls and scalariform perforation plates. Phloem sieve tubes and companion cells have thin primary cell walls. Phloem fibres have evident and thick secondary cell walls.

\section{DISCUSSION}

Myrceugenia rufa shares a number of anatomical features with other Myrtaceae. These characters include druses (calcium oxalate crystals), internal phloem and secretory cells. Calcium oxalate crystals are abundant in the leaves of M. rufa, especially in the palisade parenchyma, just below the adaxial epidermis. Druses are widely present in several genera of Myrtaceae, in diverse vegetative and reproductive structures. Donato \& Morretes (2007) and Alves et al. (2008) described druses of calcium oxalate in South American species of Eugenia. Donato \& Morretes (2011) reported the same structures for Myrcia multiflora. Polyhedral crystals, including druses, have been reported in Psidium, Eugenia, Gomidesia and Myrcia, among others (Cardoso et al. 2009, Gomes et al. 2009). The function of these structures is not completely clear, but has been related to the regulation of calcium and other minerals (Volk et al. 2002), as well as protection against herbivores and pathogens (Franceschi \& Nakata 2005, Korth et al. 2006).

Internal phloem was found in all vascular bundles of leaves, either as continuous tissue or strands in the adaxial side of the midrib. This character is regarded as a typical anatomical character in the order Myrtales (Cronquist 1981, Takhtajan 1980) and is widely present in Myrtaceae (Schmid 1980, Cardoso et al. 2009).

It is relevant to know whether internal phloem is derived from the procambium, procambially derived or pith/mesophyll cells. This developmental difference may be important at the specific or generic level and it is regarded as a potential taxonomic character (Patil et al. 2009). The ontogeny of this tissue has not been studied in Myrceugenia.

Helical wall thickenings on vessel elements wall have been reported in a number of Myrtaceae genera, such as Myrceugenia, Myrtus, Austromyrtus, Myrcia, Myrcianthes and Psidium (Schmid \& Baas 1984). Similarly, scalariform perforation plates on the end wall of vessels in Myrceugenia, Luma, Tepualia, Ugni, Neomyrtus and Myrtastrum have been 

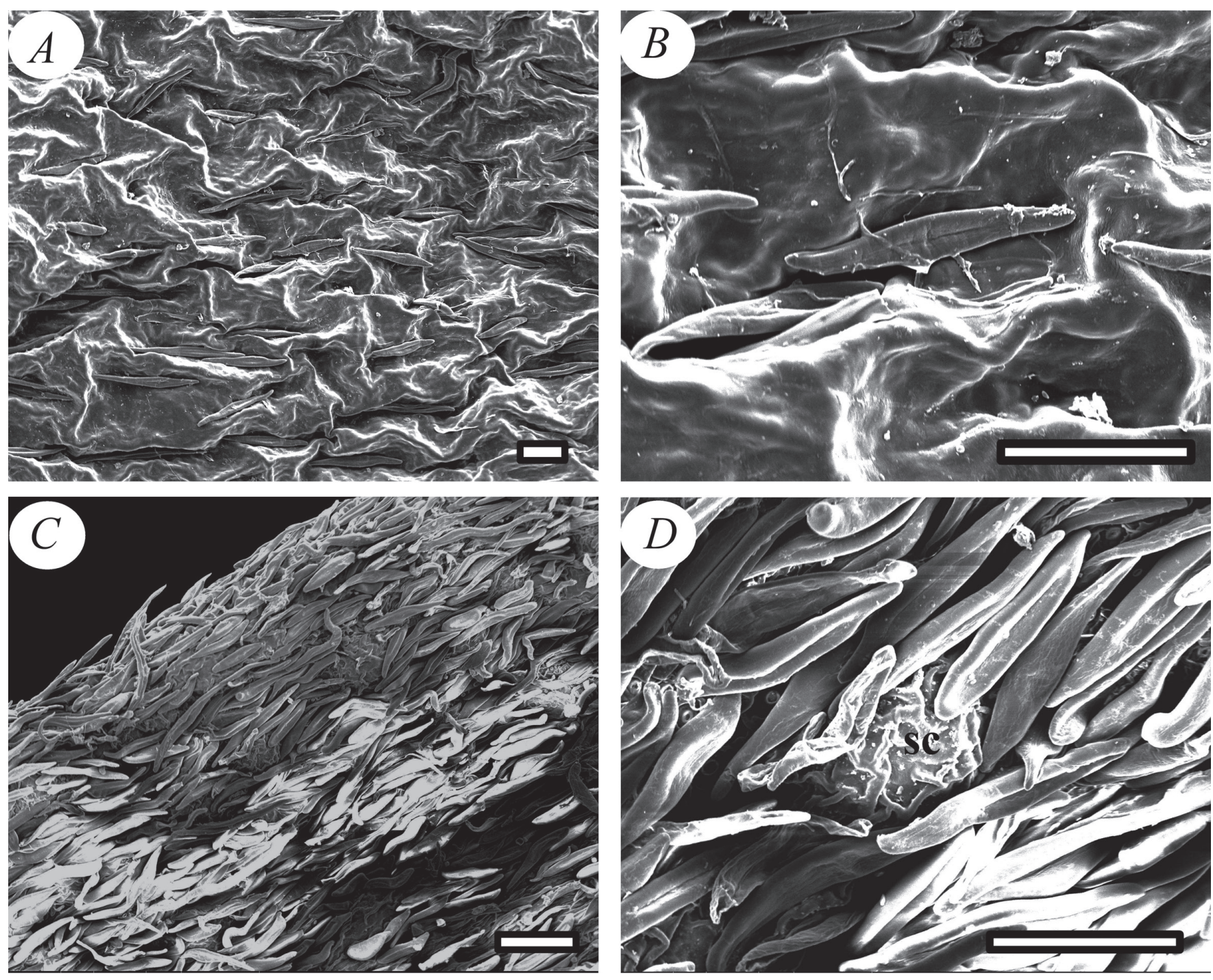

Figure 1. Scanning electron micrographs of leaves of $M$. rufa. A, Adaxial surface showing epidermal cells, epicuticular wax and scattered hairs. B, Details of hair on the adaxial surface. C, Abaxial surface with high density of dibrachiate hairs. D, Detail of a substomatal chamber covered by hairs. sc- stomatal chamber, Scale bars $=100 \mu \mathrm{m}$.

Figura 1. Microfotografías electrónicas de barrido (SEM) de las hojas de M. rufa. A, Superficie adaxial mostrando células epidermales, cera epicuticular y pelos dispersos. B, Detalle de los pelos en la superficie adaxial. C, Superficie abaxial con alta densidad de pelos unicelulares y no glandulares. D, Detalle de cavidad subestomática cubierta de pelos. sc- cavidad subestomática, Barra $=100 \mu \mathrm{m}$.

identified (Schmid \& Baas 1984). Scalariform perforation plates and helical wall thickenings on vessel walls, both found in M. rufa, have been attributed to putatively primitive species (Stern 1978). The latter, possibly as an adaptation of a common ancestor to cooler or mountain environments (Jansen et al. 2004). However, this has not been tested in detail in a phylogenetic context for the species.

The secretory ducts follow the typical schizogenous pattern commonly observed in Myrtaceae (Alves et al. 2008, Donato \& Morretes 2007, Gomes et al. 2009). Has been reported that the ontogeny of secretory ducts in Myrtus communis follows an schizolysigenous development, which begins as lysigenous and ends as schizogenous (Ciccarelli et al. 2008). Developmental studies should be conducted on $M$. rufa in order to confirm this double pattern. Volatile oils produced by secretory cavities in Myrtaceae have been identified as flavonoids (Wollenweber et al. 2000) and terpenoids (Judd et al. 1999, Lee 1998, Tanaka et al. 1996). Moreover, the occurrence of three types of secretory colleters (petaloid, conic and euryform) has been reported in different tribes of Myrtaceae, including Myrteae (Da Silva et al. 2012). These structures were not observed on $M$. rufa. 

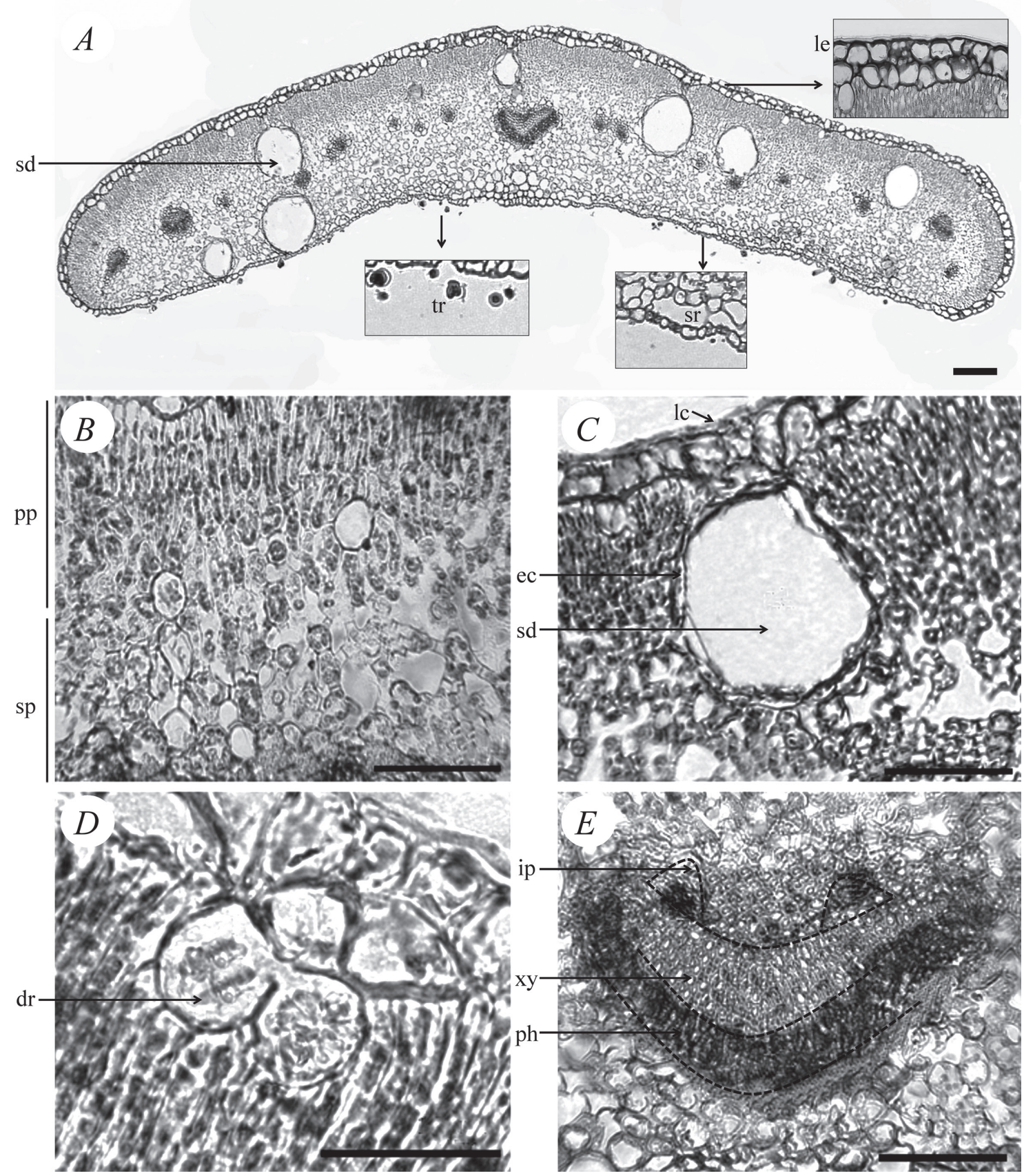

FigURE 2. Light micrographs of transverse sections of the leaves of $M$. rufa. A, General view of the anatomy of the entire leaf blade; insets show multicellular hairs (tr), large substomatal chambers (sr) and multiple epidermis (le). B, Details of the mesophyll showing compressed palisade and spongy parenchyma. C, Detail of secretory duct and epithelial cells. D, Prominent idioblasts containing druses (calcium oxalate crystals) below the double epidermis and surrounded by the mesophyll. E, Section through the midrib showing the vascular bundle with internal phloem. Dotted lines in E show differentiation between xylem and phloem in the midrib. dr- druse, ec- epithelial cell, lc- leaf cuticle, le- leaf epidermis, ip- internal phloem, ph- phloem, pp- palisade parenchyma, sd- secretory duct, sp- spongy parenchyma, sr- substomatal chambers, tr- trichomes (hairs), xy- xylem. Scale bars $=50 \mu \mathrm{m}$.

FiguRA 2. Microfotografías ópticas de secciones transversales de hoja de M. rufa. A, Vista general de la anatomía foliar; recuadros muestran pelos unicelulares (tr), cavidades subestomáticas amplias (sr) y epidermis múltiple (le). B, Detalle del mesófilo mostrando parénquima en empalizada y esponjoso. C, Detalle de cavidad secretora esquizógena con células epiteliales. D, Prominentes idioblastos con drusas (cristales de oxalato de calcio) bajo la epidermis y rodeados por el mesófilo. E, Sección transversal del haz vascular central con floema interno. Líneas punteadas en E indican diferenciación entre xilema y floema en el haz central. dr- drusa, ec- células epiteliales, lc- cutícula foliar, le- epidermis foliar, ip- floema interno, ph- floema, pp- parénquima en empalizada, sd- cavidades secretoras, sp- parénquima esponjoso, srcavidad subestomática, tr- tricomas (pelos), xy- xilema. Barra $=50 \mu \mathrm{m}$. 
Although the leaf anatomy of M. rufa shows similarities with that of other Myrtaceae species, the observed traits appear to be mainly associated with adaptations to an arid environment. Unlike almost all other species of Myrtaceae, the leaf epidermis is double-layered instead of being singlelayered. The presence of a single epidermis has been reported for Eugenia (Armstrong et al. 2012, Donato \& Morretes 2007, 2009, Esposito-Polesi et al. 2011, Fontenelle et al. 1994), Myrcia, Campomanesia (Gomes et al. 2009), Callistemon, Eucalyptus, Melaleuca (Tantawy 2004), Acmena, Syzygium, Heteropyxis, Tristania (Keating 1984) and the Chilean genus Amomyrtus (Retamales \& Naulin 2010). A single epidermis is widely associated with mesophytic and hydrophytic species and it is considered the normal type of epidermis in vascular plants (Dickison 2000). Myrceugenia euosma, regarded as morphologically similar to $M$. rufa, possesses a hypodermis on the adaxial side (Cardoso et al. 2009). Psidium and Pimenta are other two genera of the family reported to possess a double epidermis (or possibly hypodermis) (Cardoso et al. 2009, Gomes et al. 2009, Tantawy 2004). There are no developmental or ontogenetic studies of leaf epidermis in Myrteae, in order to confirm whether the origin of this tissue is protodermal (double epidermis) or from the ground meristem (hypodermis). An unusually thick cuticle was observed in $M$. rufa, being close to $50 \%$ thicker than that observed in mesophytic Chilean Myrtaceae, such as Amomyrtus luma and A. meli (Retamales \& Naulin 2010). A thick cuticle and a multilayered epidermis are normally related to xerophytic plants, which prevent water losses due to excessive evapotranspiration (Dickison 2000, Esau 1953, Metcalfe \& Chalk 1979). However, some studies suggest that the concentration of hydrophobic compounds in the cuticle are more important than the overall thickness of the cuticle for drought tolerance (Price 1982). In the case of Myrtaceae, this assumption has not been studied. Leaves of M. rufa possess scattered hairs on the adaxial surface and a dense layer of hairs on the abaxial side. The occurrence of a dense layer of hairs and other trichomes is regarded as a xerophytic adaptation (Esau 1953, Raven et al. 2005). Unlike M. rufa, leaves of Myrtaceae are often glabrous or possess scattered hairs on midribs and leaf blades (Wilson 2011). $M$. eousma is a species of the genus that has also a dense layer of hairs on the abaxial surface (Cardoso et al. 2009). In plants, the presence of hairs extends the boundary layer in a leaf (Ehleringer 1985) which creates a stable microclimate on the surface and reduces water losses due to excessive solar radiation (Riederer \& Schreiber 2001). Large substomatal chambers covered by hairs are another feature commonly found in xerophytic species, but not usual in Myrteae. $M$. eousma also shows large substomatal chambers on the abaxial side, which is covered by hairs (Cardoso et al. 2009).

The presence of vertical and thin palisade cells in the mesophyll, as those found in this study, might be related to evolution of plants in open spaces, as bushlands (Chatelet et al. 2013).

\section{CONCLUSION}

In this study, the leaf anatomy and micromorphology of Myrceugenia rufa has been described for the first time. There are anatomical similarities between the species and other Myrtaceae taxa, particularly in terms of typical characters in the family. Additionally, this paper has explored the possible xeromorphic condition of the taxon based on character differences with the common anatomy of mesophytic Myrtaceae.

The anatomical study supports the xerophytic environmental adaptations of $M$. rufa including coriaceous leaves, a thick cuticle, double-layered epidermis, a dense palisade parenchyma, abundant hairs, and partially hidden stomata. These anatomical characters are unusual in Myrtaceae, particularly in South American species. Normally, Myrtaceae taxa possess mesophytic or hydrophytic adaptations, opposite to the features described in this study. Some anatomical characters shared with other non-xerophytic Myrtaceae are oil secretory ducts, idioblasts containing druses and internal phloem in vascular bundles. Qualitative characters, particularly xerophytic, were consistent and did not show great variation across the individuals studied. Even samples from cultivated specimens did not show qualitative variation on xerophytic characters.

The origin of $M$. rufa might be related to geographic isolating events in southern South America 10-20 million years ago, such as the uplift of the Andes during the Miocene and the presence of the formation of the Arid Diagonal of South America (Landrum 1981a, 1981b, Hinojosa \& Villagrán 1997). These conditions could explain the evolution of endemic taxa with characteristics differing from the common hydrophytic-mesophytic Myrtaceae. Whether the xerophytic characteristics of $M$. rufa are autapomorphies or shared traits with other Myrceugenia is unclear. Recent molecular phylogenetic analyses of Myrceugenia indicate that $M$. rufa is sister group to all the other Chilean and Brazilian species of the genus (Murillo-A et al. 2013).

Incorporating these morpho-anatomical findings in future studies, particularly phylogenetic analyses, can provide a better understanding of the evolution of this species and other anomalous taxa within the family. The comprehensive use of morpho-anatomical characters in a broad phylogeny of Myrtaceae including all the species of Myrceugenia is recommended. For this purpose, future anatomical studies will include Myrcianthes coquimbensis and all the species of Chilean Myrceugenia. This approach would allow testing whether the evolution of Myrtaceae species with xerophytic features is convergent or homologous and would also contribute to the evidence that can be used in evolutionary studies. 


\section{ACKNOWLEDGMENTS}

We thank the University of Chile, the National Botanical Garden of Chile (Viña del Mar) and the Chagual Botanical Garden (Santiago). Also to Paulette Naulin, Adelina Manríquez and Mila Arellano (University of Chile). We thank Amy Carmichael and Rachel Hancock (Queensland University of Technology) for valuable help with imaging software, and to QUT Plant Systematics Group and Rosa Scherson for feedback.

\section{REFERENCES}

Alves, E., F. Tresmondi \& E. Longui. 2008. Análise estrutural de folhas de Eugenia uniflora L. (Myrtaceae) coletadas em ambientes rural e urbano, SP, Brasil. Acta Botanica Brasilica 22: $241-248$

Anderson, T. 1951. Techniques for the preservation of threedimensional structure in preparing specimens for the electron microscope. Transactions of the New York Academy of Sciences 13(4): 130-134.

Armstrong, L., M. Duarte \& O. Miguel. 2012. Morpho-anatomy of the leaf and stem of Eugenia pyriformis. Revista Brasileira de Farmacognosia 22: 475-481.

Belsham, S. \& D. Orlovich. 2003. Development of the hypanthium and androecium in South American Myrtoideae (Myrtaceae). New Zealand Journal of Botany 41: 161-169.

Benort, I. 1989. Libro rojo de la Flora terrestre de Chile. Corporación Nacional Forestal, Santiago de Chile. 157 pp.

Biffin, E., E. Lucas, L. Craven, I. Ribeiro da Costa, M. Harrington \& M. CRISP. 2010. Evolution of exception species richness among lineages of fleshy-fruited Myrtaceae. Annals of Botany 106: 79-93.

Cardoso, C., S. Proença \& M. Sajo. 2009. Foliar anatomy of the subfamily Myrtoideae (Myrtaceae). Australian Journal of Botany 57: 148-161.

Chatelet, D., W. Clement, L. Sack, M. Donoghue \& E. Edwars. 2013. The evolution of photosynthetic anatomy in Viburnum (Adoxaceae). International Journal of Plant Sciences 174: 1277-1291.

Ciccarelli, D., F. Garbari \& A. Pagni. 2008. The flower of Myrtus communis (Myrtaceae): Secretory structures, unicellular papillae, and their ecological role. Flora - Morphology, Distribution, Functional Ecology of Plants 203: 85-93.

Conti, E., A. Litt \& K. Sytsma. 1996. Circumscription of Myrtales and their relationships to other Rosids: Evidence from rbcL sequence Data. American Journal of Botany 83: 221-233.

CRONQUIST, A. 1981. An integrated system of classification of flowering plants. Columbia University Press, New York. 1262 pp.

Da Silva, C., L. Barbosa, A. Marques, A. Baracat-Pereira, A. Pinheiro \& R. MeIra. 2012. Anatomical characterisation of the foliar colleters in Myrtoideae (Myrtaceae). Australian Journal of Botany 60: 707-717.

DiCKISON, W. 2000. Integrative plant anatomy. Hartcourt/Academic Press, Massachusetts. 533 pp.

Donato, A. \& B. Morretes. 2007. Anatomia foliar de Eugenia brasiliensis Lam. (Myrtaceae) proveniente de áreas de restinga e de floresta. Revista Brasileira de Farmacognosia 17: 426-443.
Donato, A. \& B. Morretes. 2009. Anatomia foliar de Eugenia florida DC. (Myrtaceae). Revista Brasileira de Farmacognosia 19: 759-770

Donato, A. \& B. Morretes. 2011. Leaf morphoanatomy of Myrcia multiflora (Lam.) DC.-Myrtaceae. Revista Brasileira de Plantas Medicinais 13: 43-51.

EHLERINGER, J. 1985. Annuals and perennials of warm deserts. In: B. Chabot \& H. Mooney (eds.), Physiological ecology of North American plant communities. pp. 162-180. Springer Netherlands, Netherlands.

EsAu, K. 1953. Plant anatomy. John Wiley and Sons Inc, New York. $735 \mathrm{pp}$.

Esposito-Polesi, N., R. Rodrigues \& M. Almeida. 2011. Anatomia ecológica da folha de Eugenia glazioviana Kiaersk (Myrtaceae). Revista Árvore 35: 255-263.

FEDER, N. \& T. O’Brien. 1968. Plant Microtechnique: Some Principles and New Methods. American Journal of Botany 55: 123-142.

Fontenelle G., C. Costa \& R. Machado. 1994. Foliar anatomy and micromorphology of eleven species of Eugenia L. (Myrtaceae). Botanical Journal of the Linnean Society 116: 111-133.

Franceschi, V. \& P. NAKata. 2005. Calcium oxalate in plants: formation and function. Annual Review of Plant Biology 56: 41-71

Gifford, E. \& A. Foster. 1989. Morphology and evolution of vascular plants. Third edition. Freeman, New York. 626 pp.

Gomes, S., N. Somavilla, K. Gomes-Bezerra, S. Miranda, P. DeCarvalho \& D. Graciano-Ribeiro. 2009. Anatomia foliar de espécies de Myrtaceae: contribuições à taxonomia e filogenia. Acta Botanica Brasilica 23: 223-238.

Govaerts, R., M.P. Sobral, Ashton, F. Barrie, B.K. Holst, L.R. Landrum, K. Matsumoto, F.F. Mazine, E. Nic Lughadha, C.E.B. Proença, L.H.S. Silva, P.G. Wilson \& E.J. Lucas. 2008. World checklist of Myrtaceae. Royal Botanic Gardens, London. 335 pp.

HeChenleitner, P. 2005. Plantas amenazadas del centro-sur de Chile: distribución, conservación y propagación. Universidad Austral de Chile-Real Jardín Botánico de Edimburgo, Santiago de Chile. 187 pp.

Hildebrand-Vogel, R. 2002. Structure and dynamics of southern Chilean natural forests with special reference to the relation of evergreen versus deciduous elements. Folia Geobotanica 37: 107-128.

Hinojosa, F. \& C. Villagrán. 1997. History of the forests of southern South America. 2. Phytogeographical analysis. Revista Chilena de Historia Natural 70: 107-128.

Jansen, S., P. BaAs, P. Gasson, F. Lens \& E. SMets. 2004. Variation in xylem structure from tropics to tundra: evidence from vestured pits. Proceedings of the National Academy of Sciences of the United States of America 101: 8833-8837.

Janssonius, H., J. Moll \& S. Koorders. 1908. Mikrographie des holzes der auf java vorkommenden baumarten, im auftrage des kolonial-ministeriums. EJ Brill, Berlin. 365 pp.

Johansen, D. 1940. Plant microtechnique. McGraw-Hill, London. $523 \mathrm{pp}$.

Johnson, L. \& B. Briggs. 1984. Myrtales and Myrtaceae-A Phylogenetic Analysis. Annals of the Missouri Botanical Garden 71: 700-756.

Judd, W., C. Campbell, E. Kellogg \& P. Stevens. 1999. Plant systematics: a phylogenetic approach. Sinauer Associates, 
Massachusetts. 464 pp.

Kausel, E. 1944. Contribución al estudio de las Mirtáceas chilenas. Revista Argentina de Agronomía 11: 320-327.

Kausel, E. 1957. Beitrag zur Systematik der Myrtaceen. Arkiv för Botanik 3: 491-516.

KeAting, R. 1984. Leaf histology and its contribution to relationships in the Myrtales. Annals of the Missouri Botanical Garden 71: 801-823.

Korth, K., S. Doege, S. Park, F. Goggin, Q. Wang, S. Gomez, G. LiU, L. JiA \& P. NAKATA. 2006. Medicago truncatula mutants demonstrate the role of plant calcium oxalate crystals as an effective defense against chewing insects. Plant Physiology 141: 188-195.

Ladiges, P., F. Udovicic \& G. Nelson. 2003. Australian biogeographical connections and the phylogeny of large genera in the plant family Myrtaceae. Journal of Biogeography 30: 989-998.

LANDRUM, L. 1981a. A monograph of the genus Myrceugenia (Myrtaceae). Flora Neotropica 29: 1-135.

LANDRUM, L. 1981b. The phylogeny and geography of Myrceugenia (Myrtaceae). Brittonia 33: 105-129.

Landrum, L. 1988. The myrtle family (Myrtaceae) in Chile. Proceedings of the California Academy of Sciences 45: 277317.

LeE, C. 1998. Ursane triterpenoids from leaves of Melaleuca leucadendron. Phytochemistry 49: 1119-1122.

Lucas E., S. Harris, F. Mazine, S. Belsham, E. Lughadha, A. Telford, P. Gasson \& M. Chase. 2007. Suprageneric phylogenetics of Myrteae, the generically richest tribe in Myrtaceae (Myrtales). Taxon 56: 1105-1128.

McVaugh, R. 1968. The genera of American Myrtaceae: an interim report. Taxon 17: 354-418.

Metcalfe, C. \& L. Chalk. 1979. Anatomy of the dicotyledons. Clarendron Press, Oxford. 240 pp.

maA, Ministerio del Medioambiente. 2013. Decreto Supremo 13/2013. Aprueba reglamento de clasificación de especies silvestres según estado de conservación. Diario Oficial de la República de Chile. Publicado el 27 de abril de 2012.

Murillo-A, J., E. Ruiz, L. Landrum, T. Stuessy \& M. Barfuss. 2012. Phylogenetic relationships in Myrceugenia (Myrtaceae) based on plastid and nuclear DNA sequences. Molecular Phylogenetics and Evolution 62: 764-776.

Murillo-A, J., T. Stuessy \& E. Ruiz. 2013. Phylogenetic relationships among Myrceugenia, Blepharocalyx and Luma (Myrtaceae) based on paired-sites models and the secondary structures of ITS and ETS sequences. Plant Systematics and Evolution 299: 713-729.

Patil, V., K. RaO \& K. RaJPut. 2009. Development of intraxylary phloem and internal cambium in Ipomoea hederifolia (Convolvulaceae). Journal of the Torrey Botanical Society 136: 423-432.

Price, C. 1982. A review of the factors influencing the penetration of pesticides through plant leaves. In: D. Cutler, K. Alvin \& C. Price (eds.), The plant cuticle, pp. 237-252. Academic Press, London.

Ragonese, A. 1978. Caracteres anatómicos del parénquima radial y axial en el leño de las Mirtaceas. Darwiniana 21: 27-41.
Raven, P., R. Evert \& S. Eichhorn. 2005. Biology of plants. WH Freeman and Company, New York. 706 pp.

Record, S. \& R. Hess. 1943. Timbers of the new world. New Haven, Columbia. $640 \mathrm{pp}$.

Retamales, H. \& P. Naulin. 2010. Anatomical description of the leaves of Amomyrtus (Burret) D. Legrand et Kausel (Myrtaceae). Chloris Chilensis: 12, 2. URL: www. chlorischile.cl Viewed April 30, 2014.

Riederer, M. \& L. Schreiber. 2001. Protecting against water loss: analysis of the barrier properties of plant cuticles. Journal of Experimental Botany 52: 2023-2032.

Ruzin, S. 1999. Plant microtechnique and microscopy. Oxford University Press, New York. 322 pp.

Schmid, R. 1980. Comparative anatomy and morphology of Psiloxylon and Heteropyxis, and the subfamilial and tribal classification of Myrtaceae. Taxon 29: 559-595.

SCHMID, R. \& P. BAAs. 1984. The occurrence of scalariform perforation plates and helical vessel wall thickenings in wood of Myrtaceae. IAWA Bulletin 5: 197-215.

Serra, M., R. Gajardo \& A. Cabello. 1986. Programa de protección y recuperación de la flora nativa de Chile. Ficha técnica de especies amenazadas II: Especies raras. Departamento de Silvicultura y Manejo. Facultad de Ciencias Agrarias y Forestales, Universidad de Chile - Departamento de Áreas Silvestres Protegidas, CONAF. Santiago de Chile.

SoH, W. \& J. Parnell. 2011. Comparative leaf anatomy and phylogeny of Syzygium Gaertn. Plant Systematics and Evolution 297: 1-32.

STERN, W. 1978. A retrospective view of comparative anatomy, phylogeny, and plant taxonomy. IAWA Bulletin 2: 33-9.

TAKHTAJAN, A. 1980. Outline of the classification of flowering plants (Magnoliophyta). The Botanical Review 46: 225-359.

Tanaka, T., Y. OriI, G. Nonaka, I. Nishioka \& I. Kouno. 1996. Syzyginins A and B, two ellagitannins from Syzygium aromaticum. Phytochemistry 43: 1345-1348.

Tantawy, M. 2004. Morpho-anatomical study on certain taxa of Myrtaceae. Asian Journal of Plant Sciences 3: 274-285.

Thornhill, A. \& M. CrisP. 2012. Phylogenetic assessment of pollen characters in Myrtaceae. Australian Systematic Botany 25: 171-187.

Volk, G., V. Lynch-Holm, T. Kostman, L. Goss \& V. Franceschi. 2002. The role of druse and raphide calcium oxalate crystals in tissue calcium regulation in Pistia stratiotes leaves. Plant biology 4: 34-45.

Wilcox, C., S. Dove, W. McDavid \& D. Greer. 2009. ImageTool 3.0. Free image processing and analysis program. Department of Dental Diagnostic Science, University of Texas, Texas.

WiLson, P. 2011. Myrtaceae. In Kubitzki, K. (eds.), The families and genera of vascular plants. Vol. X. Flowering plants Eudicots: Sapindales, Cucurbitales, Myrtaceae, pp. 212-271. SpringerVerlag, Heidelberg.

Wilson, P., M. O’Brien, M. Heslewood \& C. Quinn. 2005. Relationships within Myrtaceae sensu lato based on a matK phylogeny. Plant Systematics and Evolution 251: 3-19.

Wollenweber, E., R. Wehde, M. Dörr, G. Lang \& J. Stevens. 2000. C-Methyl-flavonoids from the leaf waxes of some Myrtaceae. Phytochemistry 55: 965-970.

Recibido: 22.05.14

Aceptado: 07.02.15 